\title{
EL IMAGINARIO POÉTICO DE LA FLORA Y LA NATURALEZA EN JULIO HERRERA Y REISSIG
}

Carmen V. Vidaurre

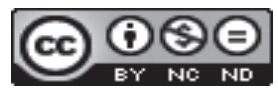

Esta obra está bajo una licencia Creative Commons Reconocimiento-No Comercial-Sin Obra Derivada 



\title{
EL IMAGINARIO POÉTICO DE LA FLORA Y LA NATURALEZA EN JULIO HERRERA Y REISSIG
}

\author{
THE POETIC IMĀGINĀRIUS ABOUT THE FLORA AND THE \\ NATURE IN HERRERA REISSIG'S WORKS
}

Carmen V. Vidaurre

\begin{abstract}
RESUMEN
Partiendo de las observaciones sobre la metáfora formuladas por Michele Prandi en su Gramática filosófica de los tropos, pero desde una perspectiva que resulta más afín a la filosofía del lenguaje de Voloshinov, estudiamos un conjunto de versos del poeta uruguayo Julio Herrera y Reissig, con el propósito de identificar los trazados ideológicos que se hacen manifiestos en diversos recursos literarios utilizados por el escritor. Nuestro corpus de estudio se centra principal, aunque no exclusivamente, en las referencias a la flora y la naturaleza, porque el léxico de la flora es recurrente en muchos de sus primeros poemas, reapareciendo luego, aunque con otras modalidades distintas en su obra poética.

Palabras clave: figuras poéticas, Julio Herrera y Reissig, análisis literario, modernismo, literatura hispanoamericana.
\end{abstract}

\begin{abstract}
Starting with one of the comments on the metaphor, made by Michele Prandi in his Philosophical grammar of tropes, but from a perspective that is more akin to the philosophy of language Voloshinov, we study a set of verses of Uruguayan poet Julio Herrera and Reissig, in order to identify the ideological paths that become manifest in some of the various literary devices used by the writer. Our corpus study focuses mainly, but not exclusively, references to flora and nature, but also because the analysis lexicon flora is recurrent in many of his early poems, then reappearing, although with other different ways in poetry.

Key words: poetic figures, Julio Herrera y Reissig, literary criticism, modernism, Hispanic literature.
\end{abstract}

\section{La metáfora como portadora de contenidos ideológicos}

En su Gramática filosófica de los tropos, M. Prandi (1995, pp. 16-26) destaca que los tropos que imponen una analogía "virtual" (como la metáfora) a un marco definido (componente literal) se presentan como "instrumentos de creación conceptual” (Prandi, 1995, p. 19). Esta "creación conceptual" que se materializa en los "tropos de analogía puntual", pero también

Dra. Carmen V. Vidaurre Arenas. Universidad de Guadalajara. División de Artes y Humanidades del Centro Universitario de Arte, Arquitectura y Diseño. México.

Correo electrónico: vidaurrecarmenv@gmail.com

Recepción: 27- 07- 2016

Aceptación: 17- 04- 2017 
en los de "analogía difusa", y en los de "diferencia mediatizada" (como el símil), corresponde a una forma de interpretar y representar la realidad que es adquirida culturalmente y está determinada por el contexto socio-ideológico específico del que forma parte el productor de los enunciados y en el que ha adquirido sus competencias comunicativas. Pues, como ya Voloshinov (1976, p. 71) había señalado en 1930: "la lengua es producto de una creatividad colectiva", al mismo tiempo que consideraba que: "Incontables hilos ideológicos atraviesan todas las áreas del intercambio social y registran su influencia en la palabra" (Voloshinov, 1976, p. 71). En tanto, Michel Foucault (2005, p. 221) hablaría del: "sistema general de la formación y transformación de los enunciados" como un "archivo" que se caracterizaba a partir de una "formación social", en la que tiene lugar una historia de intercambios discursivos.

En el tropo, mediante el empleo de una combinatoria que violenta ciertos usos de los signos, se obliga al receptor a poner en práctica un proceso interpretativo en el que debe darle la misma atención a la semántica producida por la "nueva combinatoria", que al significado que tienen las transgresiones y reactualizaciones realizadas para producirla, ya que en el enunciado "trópico": la "forma" de decir algo también significa, y esa "forma" implica la reinterpretación de una "dominante" (conceptual e ideológica) que se aplica en el uso más común de determinados signos y del campo de significaciones que abarcan.

Como señalaba Voloshinov (1976, p. 123): "La creatividad lingüística no puede entenderse separada de los significados y valores que contiene". Por ello, más que interesarnos por el análisis de los aspectos taxonómicos o lingüístico-estructurales de los tropos; nos interesa estudiar las implicaciones ideológicas a las que corresponde la creación conceptual que se manifiesta en ellos, que también pueden expresarse en otros elementos de una obra, sobre todo en aquellos elementos en cuya producción ha intervenido la creatividad, la construcción de lo "imaginario", entendido en el sentido llano de imaginar (crear representaciones mentales).

La observación de Prandi sobre la metáfora nos interesa también, porque en oposición a quienes consideran que la metáfora constituye un recurso para expresar "de otra forma" algo que corresponde a un enunciado "lógico" en su semántica (imponiéndole un enfoque "realista" y excluyendo la creación conceptual que involucra), Prandi señala que en este tipo de tropos se "impone una analogía virtual", lo que desde la perspectiva de Jacques Derrida (1989, p. 222) implica una "metafísica para describir relaciones entre los entes", o si se prefiere: una concepción ideológica determinada que establece identidades totales o parciales entre seres distintos, por medio de las palabras.

Desde esta perspectiva estudiamos algunos textos de Julio Herrera y Reissig, en los que se utiliza un léxico de la flora y la naturaleza.

\section{Contextualización de la obra de Julio Herrera y Reissig}

Ubicar la obra de un escritor en el contexto literario que le corresponde no es sencillo, particularmente si éste ha sido adscrito al modernismo, pues algunos historiadores insisten en establecer etapas distintas (2,3 y hasta 4) dentro del movimiento, con base en criterios de clasificación muy distintos (incluso cuando consideran lo meramente cronológico, por ejemplo: a. Ricardo Gullón habla de un "medio siglo modernista", entre 1880 y 1940; b. Otros autores fijan para el movimiento los años de 1888-1915), y hay quienes ven el modernismo como un conjunto de propuestas que desde su inicio manifestó diferencias por regiones o autores, y no tanto por épocas. Tampoco faltan quienes consideran que el movimiento mantuvo una serie de rasgos estables a lo largo de todo su desarrollo, sin considerar significativas las diferencias 
que pueden localizarse incluso en las diversas producciones de un mismo autor. Luis Rafael Hernández (2005, p. 20) afirmará: “existen tantos Modernismos como autores inmersos en esta tendencia ideo-estética". Por ello, nos limitaremos a señalar lo que algunos estudiosos han expresado sobre Julio Herrera y Reissig, pues este trabajo no tiene como objetivo un asunto que podría conducirnos a una larga polémica todavía no resuelta.

Roberto Bula (1961, p. 14) escribe: "Herrera y Reissig es quizás el poeta americano en quien los caracteres del Modernismo alcanza su expresión más vehemente”. En consonancia, Anderson Imbert (1954, p. 221) dirá: "Los diez años de producción poética de Julio Herrera y Reissig son como un redondo espejo donde se refleja de pies a cabeza la figura del modernismo". Sin embargo, Oviedo (2001, p. 334) expone que en 1900, Julio Herrera: "abandona del todo los rezagos del postromanticismo que arrastraba e inicia su etapa decadente", al mismo tiempo que lo caracteriza: "moviéndose -...- por la tangente del ciclo modernista y anunciando formas propias de la poesía contemporánea” (2001, p. 333). Nicasio Perera (1990, p. 419) lo considera: "epígono del romanticismo..., Julio Herrera y Reissig cumple todas las etapas de influencia del Parnaso, del Decadentismo, del Simbolismo, y culmina su trayectoria poética en los umbrales de la aventura estética de las vanguardias...”. Saúl Yurkievich (1976, p. 75) lo señala como precursor de los ultraístas. Manuel Alvar (1998, p. XXVIII) precisará: "Herrera y Reissig se nos manifiesta claramente modernista, pero su adhesión a la escuela fue tardía... en Uruguay el movimiento estaba ya bien orientado en 1895, en torno a la Revista Nacional de Literatura y Ciencias Sociales...”. Emir Rodríguez Monegal (1980, p. 199) ubica a Herrera en la segunda promoción de modernistas. Hugo Achugar (1985, p. 199) considera que es en 1903 cuando Herrera abandona el "neo-romanticismo impulsado por los miembros del Ateneo".

Para una adecuada contextualización literaria del autor tenemos que tomar en cuenta que el modernismo incorporó elementos de diversas tendencias, que se manifestaron con variable énfasis en cada texto. También debemos considerar lo que señala Ángeles Estévez: "En un periodo muy corto (1898-1910), Julio Herrera y Reissig no sólo compuso una extensa obra que abarcó diversos géneros sino que era dado a corregir sin límites sus escritos" (1998, p. XLVII). Por lo que para ubicar a Julio Herrera consideramos pertinente citar a Beatriz Amestoy (2008, p. 11): "su obra poética se caracteriza por una estética sincrética y por una variedad estilística que fue propia del discurso modernista". Respecto a sus relaciones con la vanguardia, valga la pena considerar que, entre otros autores, Sefamí (2000, pp. 420427) hablará de los escritores hispanoamericanos de la segunda mitad del siglo XX como "neobarrocos y neomodernistas", y este enfoque debería llevarnos a considerar seriamente las formas en que el modernismo impulsó e influyó en las vanguardias y la poesía contemporánea. Por lo que no podemos considerar que la obra del escritor uruguayo sea un caso singular de aportaciones hechas por los modernistas a las vanguardias, aunque le reconocemos un papel destacado en este punto.

Aclaramos que la organización de la obra de Herrera of rece diversas dificultades, porque "no fueron pocas las composiciones que conocieron varias publicaciones con distintas lecturas" (Estévez, 1998, p. XLII), también porque sus obras fueron ordenadas por sus editores, él sólo organizó Los peregrinos de piedra, por ello preferimos no ocuparnos de poemarios, aunque en algunos momentos seguimos un orden cronológico en este estudio.

Nos interesa analizar ciertos fenómenos textuales presentes en sus versos y la forma en que reinciden en sus producciones, siendo secundario para nosotros a qué corpus los han integrado quienes se han ocupado de editarlos o las variantes que muestran en sus distintas ediciones. 


\section{El léxico de la flora y la naturaleza en los versos de Julio Herrera y Reissig}

En los versos de Julio Herrera se hacen manifiestas personificaciones de lo que podemos llamar una "flora comestible" y se emplean recursos poéticos que involucran la humanización de la naturaleza. En el poema titulado "La velada" (Herrera y Reissig, 1978, p. 11): las legumbres, el pan y las uvas, "rezan"; mientras los campos encanecen y se muestran demacrados. La luna queda caracterizada por un candor sereno, el lago "se recoge", experimenta escalofrío, y las castañas marcan el ritmo de los corazones de quienes han compartido una velada. De este modo, el lenguaje metafórico contribuye a identificar la naturaleza y los alimentos, con lo humano.

Allen W. Phillips (1950, p. 32) había señalado respecto a las personificaciones que tienen lugar en los escritos de Herrera: "Un rasgo impresionista de la poesía de Herrera y Reissig es el uso frecuente de toda clase de metáforas personificadoras, por medio de las cuales da vida corpórea a las cosas inanimadas o abstractas". Más que un rasgo "impresionista", la prosopopeya y las diversas variedades de tropos de personificación, o que pueden implicarla, constituyen recursos poéticos de muy larga historia, pues lo mismo fueron empleadas en la literatura clásica greco-latina, medieval, renacentista, el Barroco y las vanguardias. De lo señalado dan constancia los trabajos de muy distintos investigadores, por ejemplo: a. Esteban Bérchez Castaño (2010, p. 134) observa: "en la elegía proemial Ovidio recrea una conversación entre las personificaciones de la Tragedia y la Elegía... opone el tirso de la primera; a la vara coronada de mirto de la segunda"; b. Grimaldi (2010, p. 1/5) expone una teoría de la alegoría a partir "de una descripción muy famosa de la técnica de personificación que se lee en el capítulo veinticinco de la Vita nova de Dante"; c. En la Arcadia de Lope de Vega: "la metáfora de las guarniciones de plata y de la capa verde del campo no sólo humaniza al paisaje [...y] deja adivinar... un real cuidado por la elegancia vestimentaria (Andrès, 1998, p. 161)"; d. “... el uso frecuente de las flores como metáforas de la amada... lleva a Quevedo a elaborar otras metáforas... con un carácter claramente personificador (González Quintas, 2000, p. 508)"; e. Maria Chiara D’Argenio (2006, p. 400) señala respecto a la obra de Felisberto Hernández: "El uso repetido de la personificación puede observarse en toda la obra de Hernández. La transgresión de las fronteras entre lo animado y lo inanimado, tanto en términos de los objetos como de encarnación de las entidades abstractas, no se realiza sólo por medio de la yuxtaposición de palabras... también mediante atrevidas comparaciones..."; f. "La guitarra" de Federico García Lorca: “...comienza con la personificación del instrumento musical que actúa de forma autónoma” (Serrano Begega, 2012, p. 22).

Las personificaciones implican siempre una ficcionalización, pues mediante ellas se le atribuyen características o acciones humanas a lo que no es humano, se llegan a trasgredir los límites entre lo animado y lo inanimado, entre lo humano y lo animal, lo humano y lo meramente abstracto, o entre manifestaciones físicas y lo humano, etc., y por ello también implican una determinada ontología que puede ser de variadas modalidades ideológicas, que sólo se precisa cuando consideramos los fenómenos semánticos específicos que estas figuras literarias generan: ya se trate de humanizar lo acústico, lo mineral, lo conceptual, etc.

En los versos antes referidos de Julio Herrera, las humanizaciones no son un medio por el cual se "da vida corpórea" a cosas abstractas; en cambio: se humaniza la naturaleza, el paisaje del agro, los alimentos. Es decir, las personificaciones implican darle el "valor" y la "cualidad" de lo humano a lo que forma parte del paisaje del campo y a los alimentos. Estas humanizaciones tienen matices y connotaciones específicas, pues dichos fenómenos 
se producen en un contexto verbal en el que también figuran signos que connotan la inocencia (a. "virginal"; b. "candor"; c. "corazones blancos") y hay un léxico religioso ("rezaron ya"), a lo que se añade la referencia a una situación específica en la que se consumen alimentos, y se produce una identificación y coparticipación entre distintos seres del micro-universo descrito en el poema, haciendo visible no sólo una perspectiva subjetiva que ficcionaliza, también una perspectiva religiosa que se proyecta sobre lo que el texto refiere: una escena nocturna con algunos elementos costumbristas, en la que ha tenido lugar una cena, en un escenario del campo, durante una estación invernal.

La vinculación del alimento con lo religioso forma parte de diversas tradiciones, pero los signos del poema de Herrera apuntan a una tradición judeo-cristiana, pues compartir el alimento se relaciona con una coparticipación colectiva, con un rezo, y el alimento referido incluye pan y uvas (evocando el pan y el vino de la comunión). Sin embargo, en el poema encontramos también signos de la cultura greco-latina, ya que los personajes tienen nombres latinos y griegos: a. "Lux canta"; b. "Lide corre"; c. "Anfión...". Al mismo tiempo que el placer es asociado con un "cabrío". Lo que hace visible un sincretismo, que también se expresa porque luego de la cena, semejante a una ceremonia religiosa, se describe un ambiente asociado a la fiesta popular, por las acciones enumeradas: a. "anda en zancos / todos ríen"; b. "canta"; c. "corre"; d. "saltan en el fuego". Lo que expone una mezcla de lo sacro y lo profano.

Los fenómenos de sincretismo, recurrentes en la literatura modernista, han sido asociados al cosmopolitismo. En el poema de Julio Herrera estos fenómenos no corresponden a ese cosmopolitismo del que se ha hablado, el sincretismo involucra la tradición clásica y la cristiana, al mismo tiempo que se observa la coparticipación de signos del campo semántico de la celebración popular, hechos que nos remite indirectamente a la cultura medieval, en la que la tradición greco-latina estaba todavía presente (fenómeno ampliamente estudiado por E. R. Curtius) y en la que se proyectaban elementos que adoptaban la forma de una idealización y sacralización de la vida cotidiana en el campo, coexistiendo con el establecimiento de correspondencias entre la naturaleza y el hombre, y con la presencia de prácticas religiosas católicas mezcladas con otras festivas de origen popular. Recordemos que la tradición medieval había sido rescatada por los escritores y artistas románticos, que también prodigaron un "culto a la naturaleza" y proyectaron sobre ella lo humano y lo "espiritual", dándole especial atención a los elementos costumbristas, a la revaloración de lo popular. A su vez, esa tradición romántica había sido recuperada por los modernistas, como señala Oviedo (1997, p. 137): "En cierto sentido, el modernismo rescata y revitaliza el espíritu de aquella escuela [la romántica] y lo proyecta en una dimensión nueva". Sobre la importancia que cobró la Edad Media en el Romanticismo, se ha observado: "No es extraño..., que la corriente del Romanticismo terminara por mitificar a la Edad Media... por cuanto en ella había tenido un gran predicamento la fe religiosa, a la que se contemplaba independientemente de la actuación institucional de la Iglesia" (Valdeón Baruque, 2003, p. 317).

Los investigadores señalan que la cultura grecolatina también fue recuperada por los románticos como reacción al racionalismo, para reivindicar la imaginación y el mito:

Lo que Vico había presentado, desde una perspectiva de conciencia histórica, contra el racionalismo abstracto de Descartes, la anterioridad de una era de la imaginación y del mito, por la que los pueblos primitivos eran considerados como naturalmente poetas, los románticos lo vuelven a proponer de un modo más elaborado, coherente, refinado, nutrido por un entusiasta conocimiento de la poesía de los griegos, filtrada a través de la fuente de la filosofía reflexiva de Fichte y de Kant, contra la autosuficiencia de la razón (Leocata, 2003, p. 26) 
Los puntos de contacto entre los elementos del poema de Herrera y la tradición romántica se hacen más visibles cuando consideramos lo que respecto a la obra de Bécquer se ha notado:

\begin{abstract}
La unidad panteísta de espíritu y naturaleza había sido rota por la razón; ...[Bécquer] participa de esa general actitud antirracionalista... [y procura] la reintegración de sus criaturas a esa existencia... [La] tendencia hacia lo maravilloso, fruto de la imaginación y de la fantasía, presenta en las leyendas dos vertientes: una, ligada sin duda a la tradición y al aspecto religioso... De ahí el que el espíritu cristiano, en forma de ambientes, temas y elementos costumbristas, esté tan presente en sus leyendas... (Bruguera Nadal, 2006, pp. 93-94).
\end{abstract}

Si la unidad panteísta, las tendencias a lo maravilloso, y la recuperación de lo religioso (a través de elementos costumbristas, ambientes y temas) implicaban una postura antirracionalista en los autores románticos, no podemos perder de vista que el modernismo fue heredero del romanticismo -como el positivismo lo fue del racionalismo-, y en el modernismo se asumieron también posturas subjetivas, se recuperó lo "maravilloso", lo onírico, lo mitológico y lo religioso.

Podemos observar también que los signos que se emplean en el poema de Herrera remiten a diversas experiencias sensoriales: involucran dominantemente lo cromático en contraste con el blanco (a. "la Luna nieva"; b. "lácteo escalofrío"; c. Los campos "encanecen de frío"; d. "corazones blancos"; e. "pan moreno"; f. "castañas"; g. "fuego"; h. "uvas aún lujosas de virginal rocío"), y connotan otro tipo de percepciones sensoriales: táctiles (texturas, temperaturas), acústicas (ritmos, sonidos), gustativo-olfativas (sabores), e incluso cinéticas y sinestésicas (como "lácteo escalofrío"). Esto contribuye a una descripción que no puede ser captada como una estampa descrita con palabras, en la que reconocemos detalles tradicionales (una cena, una velada, una vivienda rural, un festejo nocturno e invernal). Se trata de elementos que se alejan de la tradición romántica y corresponden a una estética modernista que:

\footnotetext{
Se propuso dar cuenta de los estados de ánimo indefinidos e inconcretos... y de los límites de la percepción (analogía de cualidades sensoriales equivalente o percepción de lo abstracto en términos sensoriales, de acuerdo con... una semántica estrictamente emocional)... [y una] visión del mundo como un bosque de símbolos donde dialogan aromas, colores, sonidos (Carnero Arbat, 2002, pp.19-20)
}

En el poema "Nivosa", las flores son utensilios para beber y proveen bebidas, los signos apelan al gozo de la experiencia sensorial que brinda la naturaleza: "Con níveo tisú se visten las acacias amorosas;/ ostentan los floripondios sus copas de porcelana/ en que siempre beberemos.../ la miel blanca de los nardos y la leche de las rosas..." (Herrera y Reissig, 1978, pp. 105-106). Aquí las flores participan de una celebración religiosa, "las nupcias de una rosa", y hacen el papel de ciertos objetos o son personificadas: "Miro a un lirio que está loco.../ va a celebrarse la danza, sobre un piano marfileño/ de dos blancas azucenas y mil pétalos de lirio" (Herrera y Reissig, 1978, pp. 105-106). Los objetos y la flora, como en el Arte Nouveau, parecen "fusionarse" morfológicamente. Las figuras poéticas contribuyen a presentar una flora ficcionalizada, próxima a la del cuento maravilloso, al mismo tiempo que se enfatiza el papel nutriente y el gozo sensorial que ofrece la naturaleza, y se ponen en juego elementos que implican una postura alejada de lo objetivo.

En estos primeros versos de Julio Herrera más importantes que las flores son: "la hierba gorda de la ribera", las praderas que sirven de alimento al ganado, los frutos y semillas que nutren, las "aceitunas y nueces", las mujeres del campo (madres que alimentan) "cuyas carnes a trébol y a tomillo trascienden". Es decir que, no encontramos una flora meramente decorativa, ornamental, la flora representada se asocia al alimento, a los aromas y texturas de un ser femenino que trasciende y nutre, de modo semejante a lo que ocurre en relación con el simbolismo de la 
"Madre Naturaleza", y la personificación de la naturaleza se une con frecuencia a un ambiente idealizado del campo en el que hay elementos que connotan lo religioso.

Muchas de las escenas plasmadas en estos versos resultan próximas a los lienzos de Jules Breton (a. Desyerbadoras, 1868. b. Al regresar de los campos, 1871, c. Fiesta de San Juan, 1875. d. Las segadoras, circa 1884. e. La salida para los campos, 1884. f. Cortadora de higos, 1873. g. Verano, 1891. h. Fin del trabajo, 1887. i. Procesión, 1888), en los que los personajes parecen inmersos en una atmósfera idealizada y matizada de espiritualidad religiosa asociada al paisaje, se describen mujeres del campo que visten de percal y trenzan en sus cabellos "tilos y azucenas", engalanadas para celebraciones sencillas. Escenas que reactualizan e idealizan modalidades de vida que corresponden a una sociedad agrícola, caracterizada en los lienzos del pintor como actividad colectiva y presentada como labor femenina asociada a lo nutriente y lo espiritual.

Es importante señalar que solo algunos de los primeros poemas de Herrera manifiestan esa proximidad a las obras de Breton, incluso en sus títulos; pues en otros, las escenas descritas tienen un enfoque paródico, sobre todo cuando la atención se centra en otros personajes del contexto rural (como el cura, el consejo, el preceptor). Enfoque que por contraste destaca la perspectiva que idealiza la naturaleza, a las figuras femeninas y a los trabajadores del campo.

En los poemas de Julio Herrera es esa vegetación que puede ser parte del alimento (“el perejil y el hinojo, el romero y el tomillo", pero también el salvado, el centeno y el trigo), la que va a ser afectada por fenómenos de sacralización, de vinculación y asimilación a lo religioso: a. "sacro olor a hinojos" (Herrera y Reissig, 1978, p. 19); b. "ecuménico amasijo de hogaza" (Herrera y Reissig, 1978, p. 20); c. "místico azafrán” (Herrera y Reissig, 1978, p. 25); d. "el rudo pan del Cielo sabe a tomillo y rosas" (Herrera y Reissig, 1978, p. 59). Pero lo más importante es que al sacralizar la flora comestible se ve a la naturaleza como la proveedora de un alimento sagrado.

En "El granjero", el poeta ofrece una botánica poética comestible cuando se indica que: a. la remolacha es "buena porque es sanguínea"; b. el "apio vil"; c. "el melón insinuante y la poma virgínea,/ el perejil humilde y la uva apolínea,/ y el ajo, maldiciente canalla del terruño" (Herrera y Reissig, 1978, p. 70). El poeta vuelve a destacar la importancia de la flora y su relación con los alimentos, enfatizar lo sensorial, y ofrece un tratado humorísticopoético de flora culinaria, al mismo tiempo que recupera la función de los bestiarios morales medievales, pues, recordemos que en los bestiarios no sólo se incluían animales reales y fantásticos, también plantas, rocas. Además: “...En ellos pesa más la valoración alegórica de las criaturas descritas que la veracidad de las descripciones. La literatura didáctica fue uno de los mecanismos que se emplearon para lograr la adhesión al ideal cristiano" (Valentini y Ristorto, 2015, pp. 13-14). Herrera le otorga a su botánica culinaria una función afín a la que le reconocen a los bestiarios diversos autores (a. Morales-Muñiz, 1996, p. 230; b. Armijo, 1996, p. 210; c. Urdapilleta, 2014, p. 239), pues los especímenes de la flora se transforman en ejemplos de diversas conductas vistas desde una perspectiva moral, presentando a las especies de la naturaleza como modelo del actuar positivo y negativo, cumpliendo también con un papel didáctico y de exempla.

Los signos que refieren a la religión se relacionan también con el campo, con los árboles: a. "el campo es un filósofo, su ley el catecismo" (Herrera, 1978, p. 61); b. "el bosque olía a mirra, como un ara... un grupo de cipreses parecía/ bajo de la capucha, hondos cartujos" (Herrera, 1978, p. 95). De tal manera que el campo, el bosque, las especies arbóreas, son identificados con seres en los que se proyecta lo subjetivo, lo humano, se manifiesta lo "maravilloso", pero también los signos de lo religioso y lo sagrado. 
Hemos observado antes que en los versos del escritor uruguayo figura una mezcla de lo sacro y lo profano, elementos que refieren a la tradición cristiana y otros de la cultura grecolatina, este último fenómeno fue identificado también por Beatriz Amestoy Leal (2008, p. 59), quien señala: "En este paisaje idealizado, en 'éxtasis', desarrollan su actividad los pastores y se enamoran. Los personajes de los idilios tienen todos nombres greco-romanos o hebreos".

Sin embargo, también encontramos referencias que remiten a diversos cultos y contribuyen a conformar un marco notablemente heterogéneo de "creencias" y valores con el cual se caracteriza la naturaleza: a. "La druídica pompa de la selva" (Herrera y Reissig, 1978, p. 17); b. "los charcos panteístas" (Herrera y Reissig, 1978, p. 18); c. "el sauce, como viejo sacerdote" (Herrera y Reissig, 1978, p. 47); d. "bello nirvana gris de la Naturaleza" (Herrera y Reissig, 1978, p. 79); e. "brahmánicas unciones” (Herrera y Reissig, 1978, p. 109); f. "Lirio Visionario" (Herrera y Reissig, 1978, p. 80); g. "la veste ensangrentada de amapolas" (Herrera y Reissig, 1978, p. 112). La naturaleza es caracterizada a partir del panteísmo y en ella se proyectan una diversidad heterogénea de cultos para sacralizarla. Podremos notar que no se trata de la presencia de una ideología feudal y católica; lo que encontramos es un nuevo culto a la naturaleza, en el que se recupera su personificación como potencia nutriente, unida a la idealización de la vida de los trabajadores del campo en una atmosfera impregnada de espiritualidad que recupera elementos de distintos cultos (considerados por Gutiérrez Girardot como signos que manifiestan una secularización problemática en los modernistas), y de cuya idealización se excluyen figuras que son parodiadas (relacionadas con el clero y las autoridades rurales).

En esos versos, la ausencia de puntos de anclaje temporal que permitan la identificación del contexto histórico y geográfico particular que se describe ha hecho concluir a los estudiosos de Julio Herrera: "No hay, pues, reproducción verista o versión fotográfica de un paisaje que pueda localizarse en un espacio y un tiempo determinados" (Amestoy Leal, 2008, p. 47). La representación de la naturaleza que no corresponde a una visión objetiva e histórica, la desvinculación entre el paisaje y un tiempo "actual" o concreto, hace que la naturaleza se nos presente como un territorio "aislado del mundo", pero también como espacio atemporal, mitificado. Esta representación de la naturaleza como espacio sustraído del tiempo histórico ha sido observada por los analistas del modernismo, en el que dicha representación constituyó un tópico identificado con "espacios secretos" del gozo sensorial, en los que se redescubre un diálogo con lo trascendente:

Aún más interesante es entrever, junto con el juego de los colores y de los perfumes, una intención litúrgica... la vocación de sustraerse a las coordenadas materiales de su propio tiempo no se contenta sólo con evocar espacios secretos en que la necesidad de una religión nueva se mezcla con ambiguas liturgias filiales... [para] redescubrir misterios que el mismo romanticismo había dejado como en soslayo... (Litvak, 1990, p. 11)

Estos elementos se unen a una concepción en la que se producen identidades y correspondencias entre el hombre y la naturaleza, entre los seres, como ha anotado Amestoy Leal (2008, p. 142) la poesía de Julio Herrera: “...trasmite su creencia en la unidad cósmica... Existe una armonía y correspondencia entre lo humano, las cosas y el paisaje, dado que comparten los mismos sentimientos".

En el poema titulado "La flauta" (Herrera, 1978, p. 16) es visible que la forma de describir el paisaje introduce lo maravilloso, borrando los límites entre la naturaleza y los seres humanos para presentarnos una naturaleza humanizada, al identificar: a. Una arboleda con alguien que tiembla de frío; b. La cumbre de una montaña con un filósofo en éxtasis; c. El viento con un músico; d. El sol con un tramoyista; e. La mañana con una figura femenina 
sonriente; f. El río con un parlanchín. Pero también, ese espacio del campo se convierte en un universo en el que los seres de la naturaleza participan de las características de otros seres, ya que mediante las figuras poéticas se identifican agua y animales, agua y flores, niebla y materias textiles, el torrente y un caballo, los estambres de las flores y el rocío, la neblina y algodones húmedos. Caracterizando la naturaleza como lugar en que las separaciones entre los seres se borran y se produce una unidad, una integración de todo, una coparticipación utópica.

Podemos observar también que los elementos del paisaje se convierten en los actantes de un espectáculo escénico (a. el sol tramoyista; b. el viento músico; c. el cauce parlero; d. la humareda invernal es un telón de seda; e. los estambres de las flores y el rocío se convierten en cien iluminaciones), transformando el espacio que corresponde a lo natural, en espacio de la representación teatral de las emociones y los estados de ánimo, representación interpretada por la naturaleza, identificando naturaleza y arte.

En otras ocasiones, el poeta se identifica totalmente con "una selva huraña", pero también nos habla de: a. “...[su] jardín de pálido poeta... [que] con azucenas de orfandad se viste" (Herrera y Reissig, 1978, p. 183); b. Un "bosque en que giran/ elfos de ensueño y dríadas" (Herrera y Reissig, 1978, p. 185). Espacios de la naturaleza en los que el escritor se proyecta y transforma en geografías íntimas, en símbolos de su propia identidad y de sus ensoñaciones fantástico-mitológicas y artísticas.

Respecto al tratamiento que dieron los modernistas al paisaje Lily Litvak comenta, al estudiar la obra de Juan Ramón Jiménez:

\footnotetext{
El jardín, espacio temático de los más ilustres, se reconvierte en lugar mágico, encantado, separado, metáfora breve del paraíso tal y como había aparecido a ciertos arquitectos del Renacimiento, y más tarde a los cultores del mito de las ruinas en época neogótica. El jardín... se hace eco... de recientes o contemporáneas experiencias europeas que, por su parte, lo transfiguran impidiendo toda posible caída en el paisajismo verista... (1990, p. 10)
}

Destacamos que hay en estas representaciones poéticas del jardín y la naturaleza un claro deslinde de las posturas que veían la naturaleza desde el enfoque del positivismo científico, y no sólo un alejamiento del verismo paisajístico, como señala Litvak.

Los fenómenos hasta ahora identificados en la poesía de Julio Herrera hacen evidente la presencia de un sincretismo religioso y una postura anti-racionalista, que se manifiesta en la construcción creativa de figuras literarias, así como por un énfasis en los subjetivo y la fantasía, y por una interpretación de la naturaleza afín a la concepción que tuvieran las románticos: al representar a la naturaleza como espacio en el que lo trascendente y lo sagrado se materializan, y del que proviene el gozo sensorial y lo nutriente, que al unirse a juegos de correspondencias expresan una comunión entre la naturaleza y lo humano e involucran una metafísica panteísta.

El panteísmo estuvo presente en los idealistas alemanes y los románticos. Sánchez Calvo (1989, p. 144) observará respecto a Shelley: “aplicó a la poesía el panteísmo de Spinoza, según el cual todos los seres son parte de la 'sustancia única', la sustancia divina..., Dios no es más que la Naturaleza”. Cinta Canterla (1997, p. 53) dirá sobre el romanticismo: "en este contexto el alma del mundo es concebida también como alma del hombre, por lo que los planteamientos idealistas y los místicos acaban confluyendo". El misticismo asociado a la contemplación de la naturaleza, como acto de revelación estaba: "despojado en el romanticismo de sus antiguas connotaciones teológicas y religiosas... [ligadas a] la tradición cristiana” (Canterla, 1997, p. 56), que fueron substituidas por la noción de "inspiración" y se vinculaba a una teoría de las correspondencias: 
...para los románticos, la naturaleza encierra un sentido oculto espiritual... De hecho, el propio Swedenborg sostenía que la naturaleza era un lenguaje mediante el que lo espiritual se manifestaba permanentemente; y su doctrina de los representativos y las correspondencias tuvo gran influencia en numerosos autores... [implicaba una] íntima conexión entre la naturaleza y el mundo espiritual... (Canterla, 1997, p. 58)

Lo antes señalado nos permite identificar puntos de contacto entre el romanticismo y la poesía de Julio Herrera, pero también permiten identificar relaciones entre romanticismo y modernismo, pues fenómenos afines a los antes descritos han sido observados en la obra de otros autores modernistas. Allen W. Phillips señala, por ejemplo, al estudiar la poesía de José Martí:

Creo posible hablar de una poética de la Naturaleza en la obra de José Martí. La estrecha interrelación entre Espíritu
y Naturaleza constituye la cifra esencial de su pensamiento... las imágenes tomadas de la Naturaleza en la obra de
Martí trascienden el propósito meramente descriptivo o plástico y tienen raíces más hondas, de índole filosófica
y religiosa... No sólo intuye Martí en el Universo las armonías ocultas y los enlaces luminosos que lo rigen, sino
que también los objetos naturales contemplados por el poeta se llenan de profundo contenido espiritual... [en] esa
comunión con la Naturaleza el ser humano llega a... captar las conexiones secretas que dan unicidad a la creación
(Phillips, 1974, pp. 241-242)

Concepciones afines a éstas se pueden localizar en las obras de muchos autores adscritos al modernismo: a. En la saga mítica de Las montañas del oro de Lugones, donde la flora es asociada con diversos cultos; b. En Pedro Prado, para quien la naturaleza es un cúmulo de percepciones sensoriales que descubren un "mundo ignorado"; c. En De sobremesa de Silva, en la que se recupera y reinterpreta la concepción romántica de la naturaleza y su relación con lo trascendente y con el arte. Lo mismo ocurre en la poesía de Gutiérrez Nájera y de Darío: d. En el elogio al paganismo de Exóticas de González Prada hay elementos pan-vitalistas, al mismo tiempo que se destaca la relación armoniosa y creativa con la naturaleza.

Podemos afirmar que si los románticos se oponían a las concepciones mecanicistas y racionalistas de la naturaleza (Kwiakowska-Szatzschneider, 1993, p. 106); los modernistas reaccionan ante las concepciones de la naturaleza propias del positivismo y la sociedad industrial, mediante un culto a la naturaleza, identificada también con el arte y el escritor.

Puntos de contacto entre el modernismo y el Art Nouveau (llamado Modernismo en España) han sido estudiados por Lily Litvak, quien ha señalado: "acudieron a las flores por su belleza, pero sobre todo porque a través de ellas llevaban a cabo una espiritualización de la materia" (2013, p. 135). Far-Becker (1996, pp. 9-16) describe la forma en que los artistas modernistas identificaron naturaleza y arte, e hicieron de la naturaleza el modelo del arte, rindiéndole culto. En los versos del escritor uruguayo, el poeta mismo se identifica con la flora y en ocasiones, asimilado a la naturaleza, se ofrece a la sacralización mediante el discurso amoroso (Herrera y Reissig, 1978, p. 78).

Litvak ha estudiado el tópico de la mujer-flor que se manifestó en la literatura y el arte modernistas. La mujer-flor tiene también algunos ejemplos en la poesía de Julio Herrera, se trata de flores personificadas que representan arquetipos de lo femenino ideal, tópico relacionado con anécdotas amorosas en los versos del uruguayo: a. "Dolores, la más discreta / violeta que me perfuma” (Herrera y Reissig, 1978, p. 118); b. “iPliega tu faz, mi Lirio!” (Herrera y Reissig, 1978, p. 120); c. "arden en su halo espectral de heliotropo" (Herrera y Reissig, 1978, p. 122). También encontramos imágenes en las que sólo una parte de la figura femenina es identificada con la flor: a. En "Rendición" se señala la faz de rosas de una joven; b. En otro poema se describe un "rostro de gardenia" (Herrera y Reissig, 1978, p. 167); c. "La tarde... ha pintado en tus ojeras un vago jardín de lilas" (Herrera y Reissig, 1978, p. 190); d. Se habla también de una "mano cincopétala de una fragancia antigua" (Herrera y Reissig, 1978, p. 122). El símil también sirve al mismo 
propósito: e. "como un clavel, tu sonrisa" (Herrera y Reissig, 1978, p. 192). La identificación entre la figura femenina y la flor puede involucrar el tópico de la amada muerta, asimilada a una Dolorosa, como ocurre en "Crepúsculo espirita". La flor puede remitirnos simultáneamente a una mujer y a un símbolo poético: el de la rosa, es el caso del poema "Rosada y blanca". También encontramos identificaciones que incluyen árboles y flores: "en el bosque de sombra, aromado, /que el negro cabello tendido esparcía... y blanca azucena en la frente del día" (Herrera y Reissig, 1978, p. 135). La personificación de las flores igualmente ofrece características afines a las que encontramos en "La misa de las flores" de Manuel Gutiérrez Nájera (1897, pp. 187-188), poema en que la flora y la fauna se humanizan en personificaciones próximas a las que figuran en los cuentos maravillosos y el Art Nouveau, pues Julio Herrera nos describe el noviazgo entre dos jazmines y las hojas de las rosas se transforman en el soporte de la escritura de las luciérnagas, al mismo tiempo que encontramos un concierto de alondras y ruiseñores, elementos unidos a "exotismos orientales". Este poema abunda en referencias a una flora y la fauna personificadas: “..., dos amapolas,/ se miraban mudas y ruborizadas/ un dulce granado mostraba sus frutos.../ Mientras enseñaban doctas mariposas,/ a un enjambre de orquídeas y rosas,/ su regio irisado alfabeto de prismas" (Herrera y Reissig, 1978, p. 138). Las amapolas no están aquí relacionadas con los estupefacientes, son caracterizadas como tímidas flores, orquídeas y rosas se asimilan a abejas, forman un enjambre, son presentadas como estudiantes de las "doctas mariposas", son colegialas que aprenden un "alfabeto de prismas". Al mismo tiempo, el "léxico del lujo, de la joyería" presenta a la naturaleza como poseedora de un tesoro y como riqueza ella misma ("Luciérnagas de oro... llevando en sus arcas tesoros”). Además, se producen variaciones cromáticas a partir de los detalles descritos, haciendo presentes de nuevo relaciones entre la literatura y las artes plásticas modernistas.

Menos frecuente que la mujer-flor, hay en los versos de Julio Herrera imágenes poéticas que identifican la mujer y el fruto, por ejemplo: los ojos son caracterizados como "dos uvas negras". Esta identidad entre la mujer y el fruto se concreta también en la figura fantástica del Hada-Manzana que acercándose ofrece: "aromático beso", volviendo a relacionar lo femenino y lo nutriente.

A la personificación e idealización de las flores y la naturaleza, los modernistas sumaron otros tópicos tradicionales como el del "paisaje ameno", que estará en varios de los versos de Julio Herrera asociado con anécdotas de conflicto amoroso, como ocurre en "El enojo" y "Expiación", contrastando la armonía de la naturaleza, con la disonancia de la relación amorosa.

En los versos de Herrera, las referencias a la flora no siempre adquieren un peso semántico relacionado con temas filosóficos, estéticos, ontológicos, existenciales, o religiosos, a veces se aproximan más a experiencias lúdicas, y las flores también figuran en versos que están centrados en juegos amorosos y de palabras: "Dices que mi 'margarita'/ te prometió la exquisita/ felicidad que le pides,/ deshojándose con tierna/ solicitud a tu cuita.../ En cambio tu "no me olvides".../ me da la muerte infinita/ al darme la vida eterna." (Herrera y Reissig, 1978, p. 159). De este modo se oponen la margarita y el "no me olvides", para ofrecernos una variante del jardín erótico de la poesía trovadoresca, que también recrearon los modernistas. Jardín erótico cuya presencia derivó de una tradición, pues como han observado los investigadores: "A fines del siglo pasado, varias circunstancias se combinaron para hacer de los jardines un tópico artístico y literario de fuertes connotaciones eróticas" (Litvak, 1990, p. 21), en él se recuperaba una tradición proveniente del Génesis, pero también las identificaciones de las figuras femeninas con flores y el recurso de aludir al lenguaje amoroso mediante metáforas 
que involucraban la naturaleza, para evadir la expresión explícita a la referencia sexual. De este tipo de recursos nos dan cuenta muchas de las imágenes poéticas empleadas por Julio Herrera, en las que la entrega amorosa del amante se compara con la de una flor: a. "Cual la rosa se entrega a pedazos" (Herrera y Reissig, 1978, p. 159); o el cuerpo de la mujer deseada y el acto amoroso son descritos a partir de elementos florales: b. "Es tu cuerpo de junco flexible... son tus senos montones ideales/ de camelias, jazmines y lirios" (Herrera y Reissig, 1978, p. 198); c. "la olorosa epidermis de una azucena" (Herrera y Reissig, 1978, p. 219); d. "surge gloriosa como una rosa... yo soy la sombra de ese rosal" (Herrera y Reissig, 1978, p. 226); e. "tiene la blanca desnudez de un lirio" (Herrera y Reissig, 1978, p. 253); f. "sus únicos vestidos/ están hechos con gránulos de escarcha/ y membranas de pétalos bruñidos... tiene un pliegue de flor cada contorno... hay en sus pies marfiles, tuberosas... guayacanes, caléndulas y rosas/ y nelumbos y adelfas tropicales" (Herrera y Reissig, 1978, p. 254). La referencia en esta última cita a guayacanes, nelumbos y adelfas tropicales, es significativa en cuanto a la geografía a la que nos refieren las especies de la flora, pues los guayacanes son varias especies de árboles nativos de América, en tanto que los nelumbos, o lotos sagrados, son originarios de Asia (lo mismo que las caléndulas y las rosas), en tanto las adelfas son mediterráneas, se trata de una flora cosmopolita, pero que incluye lo originario de América.

Los tópicos de la mujer-flor, la mujer-fruto y el léxico de la flora utilizada como lenguaje "amoroso", así como los tópicos del "jardín erótico" y el locus amoenus, involucran la asociación del erotismo humano con la belleza y funciones germinativas de la naturaleza. Se trata de recursos constantemente reactualizados para connotar positivamente la atracción sexual y la carnalidad del acto sexual, pero también para representar el amor y conceptos abstractos o sentimientos, identificados con la naturaleza. El término floral desempeña así la función de un eufemismo sexual o corporal, en otras ocasiones caracteriza el ser femenino ideal, o está vinculado al imaginario del relato maravilloso, pero también encontramos casos en los que mediante el referente floral se ofrece una caracterización novedosa de un personaje, o las referencias a la flora expresan percepciones, acciones, gozo sensorial, prototipos de belleza. Al asimilar algo a la naturaleza no sólo se produce una identificación, se proyecta en lo que es identificado la concepción que de la naturaleza se tiene, y en estos versos, con frecuencia, es en la naturaleza donde se encuentran los modelos del comportamiento humano, de la belleza y el arte (maestra naturaleza).

Aunque respecto a la flor se ha observado que en "el modernismo desaparece completamente la representación naturalista" (Litvak, 2013, p. 143); nos parece importante notar que en la obra de Herrera la representación "naturalista" no desaparece del todo, puede en algunos casos reducirse al color, la forma, el aroma, pero el vínculo figurativo "material" con la flor se mantiene en las descripciones y -a diferencia de lo que ocurre en la poesía de Darío donde con frecuencia la flor desnaturalizada es utilizada como símbolo de aspectos abstractos e incluso de nociones esotéricas-, en la poesía de Herrera el simbolismo de la flor parte frecuentemente de una relación sensorial y vitalista, lo que no excluye que en ocasiones represente simbólicamente conceptos sobre lo estético e incluso lo esotérico. Además, al ser utilizada para identificar sólo parte del ser femenino, da lugar a la configuración de seres híbridos floral-antropomorfos, como los del Art Nouveau.

En los versos del autor uruguayo, no será extraño que en un mismo poema se unan tópicos tradicionales con metáforas "audaces" para la época -incluso en sus primeros versos-, que manifiestan una búsqueda de innovación en la expresión verbal, creando un juego de 
contrapuntos entre la tradición y la renovación. Así por ejemplo, encontraremos el tópico del locus amoenus (Curtius, 1981, pp. 268-269, 277-279 y ss.), relacionado con una recuperación y reinterpretación de la poesía bucólica o la estampa de las costumbres rurales, en algunos casos a la manera del Siglo de Oro, en otras a la manera del romanticismo, como cuando se describe que mientras los labradores regresan a su trabajo, las cumbres se coronan de rosas, se hace mención del cura, la iglesia; pero, en contraste a esas referencias "tradicionales", vuelven a aparecer metáforas en las que se involucran asociaciones inusitadas, que tienen lugar cuando se afirma que de los sermones del cura: a. "fluyen suspiros de albahaca" (Herrera y Reissig, 1978, p. 14); b. y en los campos rudos hay "tres álamos en éxtasis" (Herrera y Reissig, 1978, p. 15), formando espectros; c. Se indica que la huerta familiar a veces es "sonámbula" y sueña en una "almohada de rosas" (Herrera y Reissig, 1978, p. 12); d. "El bochorno /sahúma con bucólicas fragancias el entorno" (Herrera y Reissig, 1978, p. 12). Las consecuencias que generan estos contrapuntos, diseminados en distintos versos, implican un fenómeno en el que un imaginario de lo "fantástico" irrumpe en el espacio rural costumbrista, y entonces: el lugar de la naturaleza pasa a ser el espacio de lo maravilloso y de lo que no se ajusta al sentido común, ni a la lógica racional.

Con frecuencia el poeta recurre a la irrupción inesperada de alusiones aparentemente dislocadas del tema o asunto básico, alejadas totalmente del realismo y del racionalismo: a. "en acordes /trampolines de agua viva" (Herrera y Reissig, 1978, p. 5); b. "la montaña sueña celestiales rutinas." (Herrera y Reissig, 1978, p. 9); c. "un sol convaleciente" (Herrera y Reissig, 1978, p. 10); d. "Madrugadora leña" (Herrera y Reissig, 1978, p. 11); e. "Los lagos se amortiguan" (Herrera y Reissig, 1978, p. 12); f. "donde laten bandadas de pañuelos en fila" (Herrera y Reissig, 1978, p. 12); g. "y palomas violetas salen como recuerdos /de las viejas paredes arrugadas y oscuras" (Herrera y Reissig, 1978, p. 13). Imágenes que configuran un universo poético de la fantasía y, en ocasiones, de lo "absurdo" e "irreal".

En la base de la estética del realismo estaba el pensamiento neoclásico y puntos de contacto estrechos con las propuestas filosóficas de Hippolyte Taine, cuyas afirmaciones mostrarían afinidades con el positivismo y el empirismo, junto a concepciones influidas por las ciencias naturales que valoraba la observación y la verdad, como principio moral. Para Taine: "La ciencia desemboca en la moral, al no buscar más que la verdad... Taine profesa un materialismo tan integral como su determinismo" (Todorov, 1991, p. 142). El paso del realismo al naturalismo y la confluencia de ambos estilos resultaban acordes a sus afinidades ideológico-filosóficas, frente a las que los artistas modernistas reaccionaron en variable grado, por motivos que han sido señalados:

\footnotetext{
Con el auge del cientificismo, el racionalismo y el utilitarismo de la era positivista, Hispanoamérica había ingresado decididamente en la órbita del capitalismo industrial, asegurando así riqueza y progreso material para ciertos estratos sociales, aunque a cambio del afianzamiento de regímenes dictatoriales y una subordinación económica a las potencias. Pero, al mismo tiempo, esas elites modernizadas compartían... una general visión domesticada o conformista de la función social del arte. (Oviedo, 1997, p. 220)
}

Las nuevas condiciones sociales y el paso del arte a un espacio de subordinación y marginalidad propiciaban la reacción modernista que se materializa en muchos recursos literarios, y como ha señalado Oviedo (1997, p. 226):

Los modernistas... ven que entre el lenguaje del artista y la realidad social se ha abierto un abismo que hace imposible la comunicación. La deseada comunicación no era, por supuesto, la que se producía en el nivel racional o consciente de la experiencia, sino de la sensibilidad y la imaginación. 
De aquí precisamente que los elementos poéticos que se "alejan del realismo", en los que el énfasis está en la imaginación, se transformen en medio de reaccionar frente las circunstancias en que está inmerso el poeta, buscando también otras formas de comunicación.

En los versos de Julio Herrera se expresa un culto a la naturaleza que respondía a situaciones sociales agudizadas en el periodo del modernismo, situaciones que permitían que el artista se identificara con una naturaleza reducida ahora a un simple medio de generar recursos (es decir, también marginada, degradada), desde el enfoque utilitarista propio de la sociedad industrial. Su poesía expresa una concepción que difiere de las concepciones desarrollada dentro del positivismo, las cuales veían la naturaleza como objeto de estudio científico, como posesión que debía ser dominada para obtener materias primas y productos comercializables. Al respecto ha señalado Corbera:

[El] positivismo materialista suponía la separación de la ciencia y el arte, pero también de la naturaleza y el hombre.
Una escisión que implicaba el... conocimiento racional de la naturaleza, reservado a una ciencia cada vez más
compleja y basada en modelos abstractos. Una división que -como ha señalado Manuel Sacristán- se correspondía
con la propia diferenciación técnica del trabajo en un determinado régimen de producción y otro de apropiación,
es decir, una diferenciación característica del sistema capitalista. Bajo esas condiciones de separación, la ciencia
abría camino hacia un desarrollo tecnológico considerado uno de los grandes motores del progreso de la sociedad
burguesa... subordinando plenamente a la naturaleza, sin considerar su posible deterioro ni el agotamiento de los
recursos... (Corbera Millán, 2014, p. 59)

La idealización de la naturaleza y el campo no industrializado en el modernismo ha sido considerada por los historiadores como indicio que correspondía al sistema económico agrícola, previo a la industrialización; sin embargo, es importante considerar que ese sistema se había visto afectado ya para entonces por los fenómenos de secularización que se produjeron a lo largo de todo el siglo XIX en la sociedad "Occidental", fenómenos de los que se ha ocupado Gutiérrez Girardot (1987, pp. 73-138), denominándolos como “desmiraculización del mundo" (1987, p. 35). Habría que tomar en cuenta también que dentro de las concepciones de los latifundistas del siglo XIX, la naturaleza era concebida también utilitariamente y como un medio de riqueza, si se quiere de una manera distinta a la del desarrollo industrial; pero no se le humanizaba, no era concebida como objeto de sacralización o culto, a pesar que muchos de los latifundistas en Hispanoamérica fueran miembros del clero o fueran católicos. El sincretismo religioso, la religión de la naturaleza y la religión del arte, eran concebidos como modalidades ideológicas alejadas de la tradición a la que los latifundistas se apegaban. Además, muchos terratenientes se adaptaron al nuevo sistema industrial y al positivismo, aunque en el contexto internacional pasaran a un lugar de subordinación y dependencia respecto a los propietarios de las tecnologías. La sociedad latifundista tradicional era reacia, en su mayoría, ante fenómenos que constituían "vías para llenar el vacío causado por la secularización y la crisis religiosa" ("paganización", “orientalismo religioso", "teosofía”, “esoterismo”, sustitutos de la religión como el "satanismo moderno" de los "poetas malditos", "sacralización del erotismo", etc.), porque la religión católica había sido un soporte ideológico en el sistema del latifundio. Además, estas nuevas creencias también constituían expresiones de una ideología que reaccionaba no sólo contra el positivismo desde la marginalidad propiciada por el nuevo sistema, también diferían de las tradiciones semifeudales inmediatas, al rendir culto a una naturaleza personificada y al adoptar tradiciones "paganas" e incluso esotéricas. La "novedad" modernista derivaba en parte de la recuperación de diversos elementos de distintas épocas y lugares. Renovación, pero también producción creativa de una combinatoria no convencional, que enfatizaba la fantasía y admitía lo irracional. Notaremos así que las singulares asociaciones que se manifiestan en 
los recursos analógicos implicados en diversas figuras poéticas sirven para crear una flora fantástica, en la que: a. El girasol es un astrólogo; b. El pino ronca su nostalgia "con latines de arcipreste" (Herrera y Reissig, 1978, p. 34); c. Un sauce es comparado con un Bautista que vierte "su hisopo sacramental" en "el lago amatista"; d. Un viejo pino "murmura"; e. "la hiedra es misántropa"; f. "la pradera huraña"; g. Los cerros están "bordados de hortalizas, de lino, mies y alpiste" (Herrera y Reissig, 1978, p. 62); h. Una casa en la montaña tiene "corpiño de rosas/ y sombrero de teja.../ y ríe como una niña” (Herrera y Reissig, 1978, p. 25); i. Las uvas son "gemas de extraños fuegos"; j. Los pámpanos son ciegos; k. La "Vendimia tiene ojos glaucos" (Herrera y Reissig, 1978, p. 63); 1. Hay "un jardín de lirios musicales" (Herrera y Reissig, 1978, p. 104). Imágenes literarias afines a las ilustraciones de Gérard de Grandville ${ }^{1}$ y Walter Crane, ${ }^{2}$ pero también a las ilustraciones de Edward Lear para su Nonsense Botany (1877), ${ }^{3}$ en las que las analogías e identificaciones rompen con la "lógica" racionalista y parecen responder al vínculo de la asociación múltiple, en la que domina lo subjetivo, pero también en la que se manifiesta la integración de todo en todo, "borrando" límites claros entre los distintos seres. Relaciones generadas del placer lúdico de lo incoherente, del humor y el cuento maravilloso de tradición popular. Estas relaciones rompen con la convención de la metáfora derivada de un nexo de semejanza visible (llamadas "metáforas analógicas", por oposición a las "metáforas arbitrarias") y dan cuenta de lo que había propiciado la reflexión sobre los recursos poéticos y sus funciones, que tiene antecedentes de los han hablado los estudiosos, en estos términos:

\footnotetext{
Schopenhauer desde la segunda década del XIX... da un paso muy importante en la configuración filosófica de la ley de la analogía, iniciada en el siglo XV1II por el sueco Swendenborg... Después de tales precedentes filosóficos, conseguirá una progresiva plasmación artística a través del parnasianismo y simbolismo franceses. En Inglaterra cabe destacar la teoría y praxis de los esteticistas, como Oscar Wilde. En Estados Unidos, en décadas anteriores, resulta capital la enseñanza filosófica y literaria de Emerson, sin olvidar después la obra de Walt Whitman... (Morales, 1992, p. 459)
}

En sus metáforas Julio Herrera se nutre lo mismo de la innovación, que de las más antiguas e inmediatamente tradiciones, esas antiguas tradiciones que Marini Palmieri señala:

\begin{abstract}
Con sus metáforas sorprendentes, herméticas para algunos, la poesía de Herrera y Reissig reanuda con la tradición retórica de un Quintiliano, por ejemplo, para quien en la metáfora se reunían nociones de lo inanimado y animado, adaptándose a las exigencias métricas, por un lado, y las de la emoción por otro. E incluso, dichas metáforas, al encerrar neologismos, entroncan con los principios elaborados en el capítulo 32 del Tratado de lo Sublime que se refieren a la divinidad que anida en la emoción de quien las crea. (Marini Palmieri, 1998, p. 1036)
\end{abstract}

Phillips considera que las metáforas que conllevan a la personificación tienden a reforzar la proyección espiritual sobre la materia, aunque es indudable que también corresponden a posturas panvitalistas y a huellas de un humanismo que otorga el valor de lo humano a determinados seres (pues no se trata de un humanismo "totalizante"). Esta ideología entra en oposición con la que se manifiesta en otros recursos también empleados por Herrera, y que Allen W. Phillips (1950, p. 35) describe así: “A veces este procedimiento de animación parece trabajar en dirección inversa ya que despersonaliza lo que tiene personalidad. El poeta, pues, en un momento de tensión imaginativa, gusta imaginarse a seres humanos en su tránsito a lo inerte". Este fenómeno corresponde a una "cosificación" o reificación de lo humano y lo viviente, y también se localiza en diversas prácticas derivadas de la industrialización, en las que el trabajo del hombre, incluso el trabajo intelectual, el arte, se ven reducidos a mercancías, se "cosifican". Por esto no es poco significativo que sean las humanizaciones las que tienen un mayor número de reincidencias en los versos, pues señalan la postura dominante manifiesta en los escritos, respecto a una tensión de tendencias confrontadas en el contexto 
social y que se inscriben a nivel metafórico en las distintas obras. Tendencias que formaban parte de la diversidad de elementos ideológicos de la sociedad que le fue contemporánea al autor, y que también se caracterizó por el cambio, por la transformación acelerada, en la que el artista y el filósofo pasaban a ser marginales en relación con los tecnólogos y científicos, y el mundo se transfiguraba vertiginosamente. Fenómenos que dejan huellas en los poemas de Julio Herrera y frente a los cuales reacciona de manera específica. Por ejemplo, en el extenso poema titulado "Naturaleza", Herrera describe el paisaje a diversas horas del día, en el canto XII de ese poema, que corresponde a una de las partes de la noche, la flora y la fauna son afectadas por una serie de símiles que evocan procesos de transfiguración, al ser asimiladas y comparadas sucesivamente con distintos seres (Herrera y Reissig, 1978, p. 258). En otro de sus poemas, caracteriza los sauces como cascadas de esmeralda, "flecos", cosificándolos, pero también los humaniza y los identifica con seres meditabundos que se entretienen en una labor filosófica, filósofos tristes: "Cascadas de esmeralda, flecos bordados,/ los sauces caen al río como cansados./ ¡Enfermos de tristeza, bañan su frente/ en la tibia piscina de la corriente,/ y al contemplar los giros del remolino/ parece que meditan sobre el destino!" (Herrera y Reissig, 1978, p. 216). Los sauces constituyeron un tópico modernista: José Juan Tablada, en un poema sintético describe un sauce mediante una enumeración en triada de símiles, "casi oro, casi ámbar, casi luz...”. Lugones afirma que el sauce "llueve sombra y llueve plata”, presentando a la vegetación como fuente de protección, confort y riqueza. Para Manuel González Prada, "en vano/ el sauce babilonio se estremece/ a la sonora caricia del río”, pues el enriquecido burgués jamás notará su presencia. Para Julio Herrera, como para Antonio y Manuel Machado, los sauces se relacionan con la tristeza, con la melancolía, parecen abatidos. El poeta uruguayo los identifica con seres que meditan sobre el destino y con los poetas.

Herrera identifica también el campo con un filósofo, traduciendo a enunciados poéticos, el postulado filosófico de Schelling, quien señalaba que: "El filósofo ha de considerar a la naturaleza de la misma manera que el Yo, con lo cual todo lo que se diga de ella será por analogía con el sujeto" (citado por López Domínguez, 1996, p. 283).

En la poesía del autor uruguayo se establece una red de identificaciones no sólo entre el hombre y la naturaleza, también entre la naturaleza y el arte: “iLos sauces: los poetas de los ríos,/ ...siempre sombríos,/ como agobiados por extraño duelo,/ buscando inspiración en la corriente.../ hacen sonar su blanda sinfonía.../ Los sauces, esas liras de follaje,/ pulsadas por el céfiro salvaje..." (Herrera y Reissig, 1978, p. 249). López Domínguez, al estudiar las concepciones de la naturaleza en la obra de Schelling, ha señalado: "La naturaleza tomará en Schelling los caracteres de una inmensa obra de arte que se produce a sí misma" (1996, p. 287). En los versos de Julio Herrera los sauces son poetas, "liras de follaje", artistas sombríos que buscan inspiración en la naturaleza que crea una sinfonía. Es decir, son sujetos y materia artística que se recrea. La cadena de identificaciones se continúa en el poema y más adelante, los sauces se presentan como leones furiosos cuya melena agitan los vientos, proyectando sobre la naturaleza la "imagen" romántica del protagonista rebelde y de agitada melena: "Y que al mover, en lucha con los vientos,/ su alborotado y flotador ramaje,/ son cual leones hambrientos/ que al rugir se revuelven en la arena,/ sacudiendo, furiosos, la melena." (Herrera y Reissig, 1978, p. 249).

El sauce se transfigura y se asimila a un instrumento musical, a un combatiente mítico, pero también es afectado por rasgos humanos y se muestra somnoliento, quebrantado y sufriente, análogo a los pensamientos del poeta: "Los sauces somnolientos... hechos de tristeza y de quebranto,/ que a imagen de mis tristes pensamientos/ les place florecer sobre su llanto" 
(Herrera y Reissig, 1978, p. 250). Las imágenes de árboles humanizados tienen una larga tradición, pero en la época algunos artistas habían hecho frecuentes las imágenes de árboleshumanos en sus obras, es el caso de Arthur Rackham, (en sus ilustraciones para la obra de James Matthew Barrie en 1906, y en las que acompañaban la obra de Friedrich de la MotteFouqué en 1909, así como en otras ilustraciones para los cuentos de los hermanos Grimm, las Fabulas de Esopo y Comus de John Milton). ${ }^{4}$ Antes que él, John William Waterhouse había representado árboles femeninos derivados de los mitos clásicos (en obras como $A$ Hamadryad, de 1895 y en Apollo and Daphne de 1908). Arthur Burne-Jones lo haría en The Tree of Forgivenes (1882) y Evelyn De Morgan en The Dryad (1885). Por su parte, los pintores románticos alemanes hicieron del árbol un protagonista principal de muchos de sus óleos y acuarelas, es el caso de Caspar David Friedrich (The Tree of Crows, 1822; The Lone Tree, 1822, etc.). Cipreses, pinos, castaños, ciruelos, melocotoneros, sauces, almendros, abundan en las obras de los representantes del modernismo. Alamedas, jardines, árboles y bosques suntuosos, pasan de los óleos, acuarelas y dibujos, a las columnas, muros y ventanas, en las edificaciones Art Nouveau, y adquieren en las obras simbolistas tintes macabros y antropomorfos, en ocasiones representando una flora sufriente, herida, dañada por el hombre. Estos artistas se identifican con la naturaleza y a ésta con el arte, con la actividad reflexiva, e interpretan la transformación como transfiguración.

Se ha discutido largamente si el paisaje descrito por Julio Herrera es un paisaje que refiere al de su propio país o no -algo más claro en los textos de Martí-, porque muchas de las especies de las que se ocupa no remiten a un territorio que pueda identificarse con el de su origen. Sin embargo, Herrera habla del ombú, característico de la pampa uruguaya, que en sus versos se transforma en figura mítica y en feroz combatiente, a la vez que esta especie es descrita como: ascetas, veteranos y reyes. Herrera toma en cuenta las características del ombú, su capacidad para almacenar agua, su crecimiento relativamente aislado en un territorio de fuertes vientos, su resistencia en un contexto que parecería marcadamente adverso para una planta, al mismo tiempo que lo identifica son seres mitológicos:

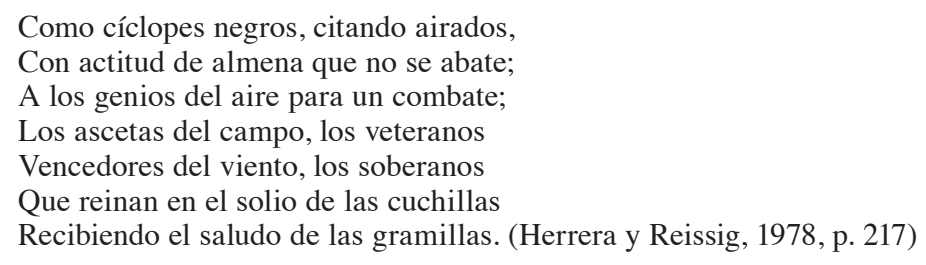

El efecto de sucesivas identificaciones incrementa la irrealidad de la descripción, al mismo tiempo relativiza la "identidad" y convierte la contigüidad en continuidad. Dado que las identificaciones no siempre responden a la analogía y el nexo parece arbitrario, también se desestabiliza la "lógica". Algunos de estos fenómenos también han sido notados por Allen W. Phillips, desde un enfoque que se orienta a la psicología, pero que destaca puntos significativos en la obra del uruguayo:

\footnotetext{
En toda una serie de metáforas insólitas, Herrera y Reissig suprime las leyes lógicas que rigen la materia... En esta des-realización quita materialidad a las cosas; se sumergen aún más en el mundo fantástico... nos invita a contemplar una realidad a veces en el proceso de transformarse, que se esfuma líricamente, para salir un momento después refrescada... por su imaginación deslumbrante. La poesía ya no está en la cosa misma, sino más bien en su íntima manera de enfocarla... En su visión más conturbada y extravagante, esta des-realización se vislumbra en la extrema tensión de la subconsciencia... De la misma composición irracional e incoherente entresacamos... versos desligados del fenómeno real... Y el nexo lógico se pulveriza (Phillips, 1950, pp. 40-41)
} 
Phillips hace notar que la des-naturalización de los colores es en los versos de Herrera otra forma de "des-realizar" lo real. Flores Mora (1947, pp. 79-81) ha hablado de la teoría del color en Herrera y su relación con la obra de Albert Samain. Debemos destacar que en Herrera encontramos una naturaleza desrealizada y fantástica, a partir de lo cromático: a. "paloma azul y oliva"; b. "camino violeta"; c. "cáscara dorada"; d. "luz verde"; e. "aire lila"; f. "blanco crepúsculo"; g. "alas de ámbar". Recursos que podemos localizar en la obra de artistas plásticos modernistas, como Hermen Anglada e Isidro Nonell, así como en los discípulos de Anglada en Mallorca, entre quienes se encontraban Roberto Montenegro, dos pintores rioplatenses (Francisco Bernareggi y Cesáreo Bernaldo de Quirós), y el uruguayo Pedro Blanes Viale (Gutiérrez Viñuales, 2003, pp. 93-121).

La identificación del poeta con la naturaleza produce otro tipo de oposiciones y en los escritos de Herrera se identifica la oposición ciudad/campo en relación con la flora, mediante versos como: "la hierba viciosa de sus calles" (Herrera y Reissig, 1998, p. 130); que contrasta con "la dulce aldea: blanca violeta de los valles" (Herrera y Reissig, 1978, p. 60). La flor también le sirve para describir la ciudad de Montevideo, a la que le dice: "tus ojos brillan como extraño fuego /y tus mejillas cual sangrientas flores" (Herrera y Reissig, 1978, p. 264). No poco significativo resulta que en el poema titulado "Esplin" [sic.], que evoca "la nostalgia de París", encontremos: a. Un Otoño convertido en un príncipe tras una vitrina, envuelto en "un pálido jubón"; b. Mientras "Flora enferma se desmaya..."; c. "Hada neblina/ fuma el opio neurasténico de un cigarro glacial" (Herrera y Reissig, 1978, p. 103); d. "una magnolia narcótica... se abre bajo un blanco crepúsculo de muerte" (Herrera y Reissig, 1978, p. 121). Se trata de enunciados en los que los elementos que refieren a la naturaleza aparecen sumergidos en una atmósfera decadente que los "degrada", por estar en la gran urbe. En estos versos encontramos también el tema de los "paraísos artificiales".

Botero Villegas observa que en diversas tradiciones clásicas la oposición tradicional campo/ciudad no involucraba la visión positiva del primero:

Recordaremos que, para los griegos, la polis era el lugar que permitía la expresión de lo que debería ser la convivencia perfecta entre los hombres: leyes, normas, sabiduría, paz, armonía, etc., estaban asociadas a la ciudad; por su parte, el campo era el espacio habitado por bárbaros, los infieles y los ignorantes... vistos como una amenaza potencial para quienes vivían en la ciudad (1997, p. 121)

Esto hace que la valoración del campo, frente a una ciudad concebida como inferior, se destaque en el modernismo como algo que rompe con una tradición y con la valoración que en la época se le daba al progreso industrial y al "progreso" identificado con las grandes metrópolis.

Es cierto que, en algunas obras modernistas encontramos que la ciudad se convierte en un punto de conexión con el mundo, aspecto que ha sido notado por Cortés Roca (2009, pp. 146-167); pero no es menos cierto que en las obras modernistas hispanoamericanas es posible identificar la contraposición ciudad/campo, representada de forma que la ciudad es vista como inferior y negativa con respecto a un campo idealizado, mitificado, interiorizado, invirtiendo una tradición que tenía su origen en la cultura clásica griega y que en las concepciones "progresistas" de la expansión industrial era muy importante, pues se interpretaba como logro llevar a los territorios en "retraso urbano", el progreso de la civilización moderna citadina. Nos referimos a la misma expansión que había generado una multiplicidad de posturas críticas y que condicionó un "sentimiento anti-industrial", que puede localizarse ya sistematizado en las obras de algunos artistas previos al modernismo: "Crisis... que había investido también el juicio sobre la urbe moderna, sobre la relación con la naturaleza, sobre los mismos valores de la vida ciudadana..." (Litvak, 1990, p. 12). Crisis derivada del impacto que las grandes 
ciudades implicaban en la vida de los grupos sociales, principalmente marginales, locales y migrantes del campo.

Si bien, la oposición campo/ciudad no se manifiesta en todas las obras modernistas, ni en todas de la misma forma, su presencia involucra una postura anti-industrial muy frecuentemente, como en el caso de Julio Herrera.

Al estudiar "los paraísos artificiales" en la obra Baudelaire, Esteban Tollinchi, anota algunos de los aspectos contextuales que condicionaron su importancia en la época:

El artista nuevo que se ha quedado sin respaldo social, religioso, económico... no tiene más recursos que a sí mismo y aun éste es carcomido por la autoconciencia, por la crítica y la ironía. En tal situación, la apelación a alternativas relativamente nuevas, dudosas, en todo caso, tenebrosas (como el alcohol, el ajenjo o las drogas) dejaría de sorprender cada vez hasta convertirse en lugar común de muchos artistas del futuro (2004, p. 153)

Aunque Tollinchi demuestra, citando al propio Baudelaire, que el escritor francés también reconoció la "esterilidad de los paraísos artificiales", da cuenta de algunas de las situaciones que hicieron que las referencias a los alcaloides y estupefacientes no fueran sólo un tópico literario. Como tópico literario este tema ha sido estudiado por varios autores, aunque tal vez en menor número que los que lo han estudiado como una realidad vital. Para citar un ejemplo del estudio del tópico haremos referencia al trabajo de Herrero Gil (2009, pp. 183-192) sobre la obra de Julián del Casal, y al de Castro Morales sobre la obra de Rodó, en el que la autora señala:

Rodó estaba trasladando (y tal vez traduciendo) la primera parte del "Poème du haschisch", titulada por Baudelaire "Le goût de l'infini", el anhelo de infinito. Y podemos comprobar que el estado "«de beatitud»" de Baudelaire corresponde al "estado glauco" de Rodó, que proporciona un "talante joven y vigoroso", así como una visión de nítidos contornos y vivísimos colores (1994, p. 216)

Un estudio más profundo sobre el tema, y que abarca varios autores modernistas, es el que ha realizado Carmen Luna Sellés (2002). Estos trabajos nos permiten señalar que la referencia a la "magnolia narcótica" formaba parte de los tópicos que se habían incorporado a la poesía de la época, como signo del contexto en el que vivía el artista, consumiera o no estupefacientes. Tópico de herencia decadentista, que como otros elementos del decadentismo se harán presente en los versos del escritor uruguayo, afectado también la representación femenina, presentada en transfiguraciones que la alejan del arquetipo de lo femenino identificado con una belleza frágil, ideal, o de la madre naturaleza, para ofrecernos otro arquetipo modernista: el de la mujer identificada con el pecado, figura agresora que es relacionada con un árbol del mal, cuyos frutos matan, como si se tratara de un Eva arbórea y terrible: "Tu cabellera violeta/ denuncia su fronda inerte/ ... / y los frutos delictuosos/ tus inauditos y briosos/ senos que dan la muerte." (Herrera y Reissig, 1978, p. 33). En relación con estas representaciones encontramos la identificación de la belleza con: a. una "amapola del sadismo" (Herrera y Reissig, 1978, p. 37); b. "lóbrega rosa" (Herrera y Reissig, 1978, p. 110); c. "rosas lascivas" (Herrera y Reissig, 1978, p. 135); así como asociaciones en las que la mujer fatal y las flores se vinculan: d. La "fusta impía" de una Amazona, "escupe rosas en la faz del día" (Herrera y Reissig, 1978, p. 108). Se trata de tópicos procedentes de la obra de Baudelaire que figura señalada expresamente en los versos de Herrera, y en los que la mujer es una "flor del mal": "Misteriosa flor erótica,/ Miliunanochesca, hipnótica,/ Flor de Estigia acre y marchita;/ tú eres absurda y maldita,.../ una hurí desesperada/ del harem de Baudelaire." (Herrera y Reissig, 1978, pp. 168-169). El tópico de la mujer agresora ha sido identificado con una época en que diversas enfermedades venéreas fueron pretexto para mitificar negativamente a la mujer, las legislaciones sanitarias parecen corroborar este punto. 
Hay que considerar que los cambios sociales, incluso en las capitales de las potencias mundiales, no eran uniformes y esto propiciaba la coexistencia de elementos del pasado con otros "actuales" en distintas zonas, incluso de Europa..$^{5}$ Además de que la ideología dominante permeaba todas las capas sociales, al ser promovida e impulsada por el Estado y los grupos dominantes, generando contradicciones en la realidad, manifiestas también en los textos de la época. A esto obedece la coexistencia de elementos románticos y decadentes en un mismo texto y la presencia de contradicciones en la representación de ciertas figuras y personajes. La yuxtaposición o copresencia de tradiciones románticas y decadentistas en una misma obra ha sido notada por otros estudiosos, como un fenómeno generalizado en la época. Oviedo señala, por ejemplo, que existe una confluencia de estilos literarios en las últimas décadas del siglo XIX:

\footnotetext{
...la secuencia realismo-naturalismo que suelen presentar nuestras historias literarias, sólo opera al comienzo del proceso, pero que luego, en su fase madura, se produce una superposición o confluencia de ambas formas, más la crepuscular romántica y la inicial del modernismo... Hacia la década del 80 todas esas fórmulas están operando simultáneamente, con diversos grados de autonomía (1997, p. 139).
}

Esta simultaneidad de propuestas genera contradicciones y ambigüedades que se manifiestan, por ejemplo, en otras representaciones de la figura femenina asimilada a la flor, pues en los versos de Herrera se le muestra simultáneamente como agresora y víctima: "propiciadora del Moloch asirio,/ fue tu cautiva doncellez de lirio/ ofrenda de guerreros y magnates" (Herrera y Reissig, 1978, p. 110). Pero si en los versos anteriores el personaje femenino es propiciadora y cautiva-ofrenda, la figura femenina también se representa con otras ambivalencias, por ejemplo, cuando se identifican los abrojos y las flores con el ser femenino -aunque remitiendo a dos tipos distintos de mujeres: "pero hay flores que tienen abrojos /y hay abrojos que tienen perfume" (Herrera y Reissig, 1978, p. 208), introduciendo de este modo una propuesta que, aunque no elimina los arquetipos, los adopta en forma menos esquemática y abre la posibilidad de ampliar la gama de representaciones femeninas. Lo que también se puede aplicar a otros elementos textuales. Por ejemplo, en la poesía de Julio Herrera hallamos una "negra flor del Idealismo" (Herrera y Reissig, 1978, p. 34), en una metáfora de la flora que involucra un concepto, pues la flor refiere a algo abstracto. Sin embargo, Herrera también recupera el símbolo ideal de la rosa: a. "un silencio de rosas dormidas" (Herrera y Reissig, 1978, p. 134); b. El amor es definido como "una rosa divina". La rosa que, como en la poesía de Yeats, es la flor invocada: "para poder contemplar la belleza más allá de los límites del destino humano" (Barbeito Varela, 2000, p. 26) y representa el ideal, como ocurre en Darío y en Lugones, que ven en la rosa un arquetipo rodeado de un halo de misticismo y de teosofía.

Oviedo considera que el decadentismo constituía una reacción "contra el progreso ilimitado" (1997, p. 227). Sin embargo, debemos precisar que esa visión pesimista, desengañada, en la que incluso lo femenino y la naturaleza fueron representadas con matices agresivos y como seres enfermos o heridos -aunque sin dejar de ser atrayentes-, corresponde a la última etapa de un romanticismo utopista que enfrentaba la derrota ante el avance de una industrialización que mostraba sus consecuencias más negativas (la proletarización del escritor y del artista, pero también de agricultores y pequeños comerciantes, de grupos sociales empobrecidos y marginados por el desempleo o los bajos salarios, confinados en zonas urbanas en las que dominaban el hacinamiento y la insalubridad, donde crecía la prostitución, el alcoholismo, el crimen, la polución, la destrucción de los entornos naturales periféricos. Masas carentes de los beneficios de la tecnología, que no tenía acceso a servicios médicos, ${ }^{6}$ ni públicos. ${ }^{7}$ Bastaría con considerar los índices alcanzados en padecimientos ${ }^{8}$ como la sífilis, el cólera y 
otras enfermedades infecciosas como la tuberculosis, el tifus, la gripe española, o cuantificar las hectáreas de bosques destruidas para hacer fábricas, vías y estaciones de trenes, almacenes, astilleros. Los altos niveles de contaminación de ríos, costas, suelos, ${ }^{9}$ que transformaban a la naturaleza, sobre todo en zonas industriales próximas a la viviendas populares, ya que fueron marcados los contrastes entre las zonas burguesas y las obreras en las grandes urbes (las fotografías de la época dan testimonio). Situaciones que sumadas a la difusión de "los paraísos artificiales" se manifestaron en la literatura y el arte en modalidades de exploración en lo irracional macabro, lo decadente. Fenómenos que si bien se mostraron primero en las potencias industriales, fueron trasladados a las zonas de su expansión.

En los poemas de Julio Herrera encontramos abundantes imágenes en las que se explora en lo irracional o macabro, en las que la flora se vincula a la misantropía, al insomnio, al sonambulismo, la alucinación: a. Cuando describe pantanos muertos en los que "lloran sus misantropías algunos sauces humanos" (Herrera y Reissig, 1998, p. 124); b. Brisas que "llevan el secreto de los insomnios" (Herrera y Reissig, 1998, p. 124); c. "diablos, reunidos en los castaños" (Herrera y Reissig, 1998, p. 124); d. "insondables arbustos de los collados" que "gesticulan"; e. "lirios sonámbulos" que "dialogan" (Herrera y Reissig, 1978, pp. 72-77). f. "un bosque alucinado por una luna exótica" (Herrera y Reissig, 1978, p. 95); g. "las ramas celebran en la umbría/ una función de ventriloquia extraña” (Herrera y Reissig, 1978, p. 102).

En ocasiones, en las imágenes poéticas que refieren a la flora se hacen presentes signos de un campo semántico de lo bélico y se representa una flora herida, pero también combatiente: a. "Tiemblan los lirios, como si heridos/ buscasen vendas entre las hojas" (Herrera y Reissig, 1978, p. 203); b. “y ostenta el ceibo sus heridas rojas" (Herrera y Reissig 1978, p. 208); c. "cada verde y lustroso limonero; / cada gajo de aroma es una llama... y hay algo de grandeza en los laureles/ que abaten sus lustrosos estandartes" (Herrera y Reissig, 1978, p. 208). Imágenes afines a éstas también podemos encontrarlas en la poesía de Lugones.

En su crítica a la concepción mecanicista de Fichte, Schelling hacía un llamado a la toma de conciencia sobre la destrucción de la naturaleza:

\footnotetext{
...sentencia Schelling, una naturaleza sometida al hombre y forzada a servir exclusivamente a los fines humanos es una naturaleza muerta, y una humanidad que, volviendo la espalda a los lazos que la unen a la naturaleza, se empeña, como lo hace Fichte... en negar a la naturaleza imponiéndole cualquier suerte de fines subjetivos, es una humanidad suicida que trabaja en su propia destrucción. (Pérez Quintana, 2003, p. 68).
}

El pensamiento romántico, y el de Schelling en particular, y su concepción de la naturaleza involucraban una solidaridad con la naturaleza y una denuncia de su destrucción, que tuvo repercusiones importantes:

Con el romanticismo se consolida una visión organicista del mundo que vincula al hombre a la historia de la
vida y del todo de la naturaleza, asociando al vínculo ontológico un deber de solidaridad del hombre para con la
naturaleza... No debe extrañar, por ello, que puedan ser identificadas en la Natürphilosophie algunas de las claves
de Organismo y libertad de H. Jonas así como de los argumentos de este autor en torno a la fundamentación, en
una Filosofía de la Naturaleza, de la ética de la responsabilidad por la naturaleza... Heidegger... defensor acérrimo
de un cambio radical del comportamiento del hombre ante la naturaleza, invoca una y otra vez al gran poeta
romántico Hölderling. Asimismo, Bloch, que recupera la oposición de Schelling a la imagen mecánico-cuantitativa
de la naturaleza en la ciencia moderna... W. Schmied-Kowarzik ha llamado reiteradamente la atención sobre el
significado de la Filosofía de la Naturaleza de Schelling, tanto para el actual pensamiento ecológico, como para el
cuestionamiento... de la naturaleza como objeto a disposición del hombre. (Pérez Quintana, 2003, p. 67).

Esa ética responsabilidad con la naturaleza se descubre en las representaciones de una naturaleza herida o transformada negativamente en algunos versos de Julio Herrera. 
Pero los tropos que Herrera crea también se vinculan con el juego y la fantasía, manifestando una práctica lúdica e imaginativa que se recupera en el lenguaje de variadas formas, por ejemplo: a. "juega el viento perfumado/ con los pétalos que arranca/ ...de un ajedrez perfumado" (Herrera y Reissig, 1978, p. 168). Además, en contraparte con la destrucción de la naturaleza propiciada por la industrialización, en los versos de Herrera toda la naturaleza y el paisaje edificado puede ser objeto de identificaciones con la flora en juegos de correspondencias múltiples. Así, por ejemplo: a. el sol es una "dalia dorada que se ha dormido sobre topacios" (Herrera y Reissig, 1978, p. 203); b. Un faro es un "bosque incendiado que se aproxima" (Herrera y Reissig, 1978, p. 204); c. "los rojos colibríes... como rosas del cielo, como flores/ teñidas en el vino de granado" (Herrera y Reissig, 1978, p. 259).

En la segunda parte de la trilogía titulada Le réve d'Alembert (1769, del Diderot traducido por Goethe) el protagonista afirma: “Tous les êtres circulent les uns dans les autres... tout est en un flux perpétuel... Tout animal est plus ou moins homme; tout minéral est plus ou moins plante; toute plante est plus ou moins animale. Il n'y a rien de précis en nature"10 (Diderot, 1769, p. 20). Diderot influyó en Baudelaire y hay quien ha señalado que la teoría de las correspondencias del poeta tiene su origen en la obra del filósofo, y en este pasaje se expresa una concepción que se hace manifiesta en los versos de Julio Herrera, en las múltiples identificaciones que se establecen entre distintos seres, asociada a una mitificación utopista relacionada con el culto a la naturaleza.

Allen W. Phillips identifica, entre las raíces filosóficas y religiosas de las concepciones de la naturaleza de Martí: el pensamiento de Emerson, Walt Whitman y Henry Ward-Beecher. Sin embargo, en el caso de Herrera, como en el de otros modernistas, tendríamos que considerar también el idealismo alemán y el legado de los románticos, entre otros el de Friedrich Schlegel: "El postulado romántico de Schlegel, cuyo fragmento programático del Athenaeum sobre la poesía romántica como 'poesía universal progresiva' proclamaba la necesidad de reunificar todo, la poesía y la prosa... de mezclar la poesía artística y la poesía de la naturaleza” (Gutiérrez Girardot, 1987, p. 89).

\section{Conclusiones}

La flora adquiere en los versos de Julio Herrera una riqueza de connotaciones y funciones amplias. Su análisis nos permite comprobar que desde sus primeros versos se hacen manifiestos recursos literarios identificados como propios del modernismo y el uso de figuras poéticas audaces, unido a concepciones afines a las del idealismo alemán y a una estética romántica, que se mantienen vigentes a lo largo de sus producciones poéticas. Nos permite observar que el decadentismo se hace más visible con el paso del tiempo, apuntando no sólo a Baudelaire, también a autores que influyeron la obra del poeta francés, sin abandonar elementos románticos. Igualmente, nos muestra afinidades en su poesía con la estética del Art Nouveau, la plástica de Jules Breton y la de otros artistas, la forma en que los tropos y tópicos literarios presentes en sus escritos corresponden a una forma de interpretar y representar la realidad, que se manifiesta también en otros autores modernistas, y en la que el culto a la naturaleza tiene de modalidades particulares, pues se vincula con una reacción ante una serie de situaciones sociales específicas presentes en la época de producción de sus versos, entre otros aspectos. 


\section{Notas}

1. Grandville, Jean Ignace Isidore Gérard de. 1840; Grandville, J. I. I. G., Scènes de la vie privée et publique des animaux, Paris: J. Hetzel et Paulin Éditeurs; y 1867. Grandville, J. I. I. G., Les Fleurs Animées. Paris: Garnier Freres.

2. Crane, Walter. 1898. A Floral Fantasy in an Old English Garden. London: Harper and Brothers; 1889. Flora's Feast, and A Masque of Flowers. London: Cassell; 1906. Flowers from Shakespeare. London: Cassell; 1905 Flower Wedding. London: Cassell.

3. Lear, E. (1877). Fourth Book of Nonsense Poems, Songs, Botany, Music. London: Robert John Bush. http://www.gutenberg.org/files/13650/13650-h/13650-h.htm

4. Rackham, A. (Illustrations by). (1906). Peter Pan In Kensington Gardens. En J. Matthew Barrie. New York: Charles Scribner's Sons. Rackham, A. (Illustrations by). (1909). Undine. En F. de la Motte Fouqué. London: William Heinemann.

5. Para quienes miden el desarrollo en términos de las cifras de producción, y no de la distribución de las riquezas, vale la pena recordar que éstas: "Incluso en el mundo desarrollado se distribuían de forma muy desigual, entre el 3.5 por 100 de la población que constituían las clases pudientes..., según la clasificación oficial francesa..." (Hobsbawn, 2009, p. 36).

6. En Inglaterra, en 1865: “de 570 ciudades afectadas por la ley de Sanidad de 1848, sólo 173 habían dotado plaza de inspectores sanitarios y de las 25 mayores sólo cinco... Las característica legislativa británica [hizo que] fueran legislados... por separado el suministro de agua a los núcleos de población (1878), las emanaciones de las fábricas de productos químicos (1881), la declaración de enfermedades infecciosas (1890), la instauración de una Inspección Médica del Trabajo (1898)” (Rodríguez Ocaña, 1994, p. 16).

7. "En Madrid, en 1902, se calculaba que, pese a la extensión del alcantarillado..., existían más de 3000 pozos negros y se señalaba que en los barrios extremos y en buena parte del caso antiguo, los sumideros carecían de sifones, mientras más de 4000 casas carecían de suministro directo de aguas..." (Rodríguez Ocaña, 1994, p. 12). Sólo hasta 1903 se generaron pautas internacionales respecto a la peste y el cólera, y en 1912, respecto a la fiebre amarilla.

8. En 1915: "no se disminuían las lacras heredadas del siglo anterior (tuberculosis, venéreas, alcoholismo, neurosis) aparecían nuevas enfermedades sociales y el medio urbano suministraba las mayores cotas de deformes e incapaces para el servicio de armas" (Rodríguez Ocaña, 1994, p. 14).

9. En el informe sobre desarrollo humano Fin de la crisis de agua y saneamiento se incluye un apartado titulado "Lecciones de la historia", en el que se señala para 1840-1880, en Londres: "La brecha entre el abastecimiento de agua y un saneamiento significó un desastre para la salud pública. Las calles y los ríos fueron altamente contaminados a causa de la creciente de residuos que llevaban las aguas... las muertes por enfermedades gastrointestinales, especialmente la diarrea en los niños, siguió siendo elevada" (2006, p. 29). El texto indica que el desfase en los servicios de saneamiento se debía a que "el sector de los industriales, quienes querían agua para sus fábricas, pero se negaban a pagar impuestos más altos para el saneamiento de la población pobre" (2006, p. 29).

10. "Todos los seres circulan unos dentro de los otros... todo es un fluir perpetuo... Todo animal es más o menos hombre; todo mineral es más o menos planta; toda planta es más o menos animal. No hay nada preciso en la naturaleza" (Traducción de la autora).

\section{Bibliografía}

Achugar, H. (1985). Poesía y sociedad (Uruguay 1880-1911). Montevideo: Arca.

Alvar, M. (1998). Liminar. Julio Herrera y Reissig. Poseía completa y prosas. (pp. XXV-XL). México: Fondo de Cultura Económica.

Amestoy Leal, B. (2008). La obra poética de Julio Herrera y Reissig: su universo imaginario. Madrid: Universidad Autónoma de Madrid. 
Anderson Imbert, E. (1954). Historia de la literatura hispanoamericana. (Vol. 2). México: Fondo de Cultura Económica.

Andrès, C. (1998). El locus amoenus en la Arcadia (1598) de Lope de Vega: intertextualidad y sensibilidad artística. En M. C. García de Enterría y A. Cordón Mesa (Eds.). Actas del IV Congreso Internacional de la Asociación Internacional Siglo de Oro (AISO). I. (pp. 153-161). Alcalá: Universidad de Alcalá de Henares. Recuperado de http://cvc. cervantes.es/literatura/aiso/pdf/04/

Armijo Canto, C. E. (1996). El bestiario medieval: una clave para la interpretación del Libro de los gatos. En A. González, L. von der Walde Moheno y C. Company (Coords.). Caballeros, monjas y maestros en la Edad Media (Actas de las V Jornadas Medievales). (pp. 205-220). México: UNAM/ El Colegio de México.

Barbeito Varela, J. M. (2000). W.B. Yeats, visionario y soñador. Garoza. (1), 21-44. Recuperado de http://webs.ono.com/garoza/G1-Barbeito.pdf

Bérchez Castaño, E. (2010). Mirto y ajenjo en la poesía romana. Minerva. (23), 127142. Recuperado de https://www.academia.edu/4051266/_Mirto_y_Ajenjo_en_la_ poes\%C3\%ADa_romana_Minerva_23_2010_pp._127-142_ISSN_0213-9634

Botero Villegas, L. F. (1997). Ciudades imaginadas, identidad y poder. Espiral. (8, 7), 113-145. Recuperado de http://www.redalyc.org/articulo.oa?id=13870806

Bruguera Nadal, M. L. (2006). De unitate speculorum. Estudios de literatura comparada. Castellón: Universitat Jaume. Recuperado de https://dialnet.unirioja.es/servlet/ libro?codigo $=268903$

Bula Piríz, R. (1961). Estudio preliminar. Poesías completas y páginas en prosa de Julio Herrera y Reissig. (pp. 7-44). Madrid: Aguilar.

Canterla, C. (1997). Naturaleza y símbolo en la estética romántica. Cuadernos de Ilustración y Romanticismo. (4-5), 53-58. Recuperado de http://revistas.uca.es/index.php/cir/article/ download/384/346

Carnero Arbat, G. (2002). La ruptura modernista. Anales de Literatura Española. (15), 13-25. Recuperado de http://hdl.handle.net/10045/7295

Castro Morales, B. (1994). Los motivos de Glauco: Rodó y el genio pagano en los paraísos artificiales. Deslindes. (4-5), 211-228.

Corbera Millán, M. (2014). Ciencia, naturaleza y paisaje en Alexander Von Humboldt. Boletín de la Asociación de Geógrafos Españoles. (64), 37-64. Recuperado de http://www. boletinage.com/articulos/64/

Cortés Roca, P. (2009). La ciudad bajo los ojos del Modernismo. A Contra Corriente. (1, 7), 146-167.

Curtius, E. R. (1981). Literatura europea y Edad Media Latina. (Vol. 1). México: Fondo de Cultura Económica.

D’Argenio, M. C. (2006). El estatuto de lo fantástico en Felisberto Hernández. Revista Iberoamericana. 72 (215-216), 395-414. Recuperado de https://revista-iberoamericana. pitt.edu/ojs/index.php/Iberoamericana/article/viewFile/89/88 
Derrrida, J. (1989). La retirada de la metáfora. La deconstrucción en las fronteras de la filosofía. (P. Peñalver, tr.). (pp. 209-233). Barcelona: Ediciones Paidós.

Diderot, D. (1769). Le rêve d'Alembert. Trilogie: 2 e texte. Québec. Bibliothèque Paul-ÉmileBoulet de l'Université du Québec à Chicoutimi. Recuperado de http://perso.wanadoo. fr/fatalisme

Estévez, Á. (Coord.). (1998). “Introducción”. Julio Herrera y Reissig. Poseía completa y prosas. (pp. XXV-LVII). México: Fondo de Cultura Económica.

Far-Becker,G.(1996).ElModernismo.(A.Sánchez,tr.).Barcelona:Kónemann Verlagsgesellschaft.

Fernández Uribe, C. A. (2004). Hipólito Taine: la obra de arte como hija de su tiempo. Artes. 3 (6), 49-63. Recuperado de http://hdl.handle.net/10495/2432

Flores Mora, M. (1947). Julio Herrera y Reissig. Montevideo: Letras.

Foucault, M. (2005). La arqueología del saber. Buenos Aires-México: Siglo XXI Editores.

Gutiérrez Girardot, R. (1987). Modernismo. Supuestos históricos y culturales. México: Fondo de Cultura Económica.

González Quintas, E. (2000). La metáfora en la poesía amorosa de Quevedo. En F. Sevilla Arroyo y C. Alvar Ezquerra (Coords.). Actas del XIII Congreso de la Asociación Internacional de Hispanistas. (Vol. 1). (pp. 578-585). Madrid: Castalia. Recuperado de http://dialnet.unirioja.es/servlet/libro?codigo=2740

Grimaldi, M. (2010). Allegoria in versi. Generi e forme nella tradizione manoscritta trobadorica. (Tesis doctoral). Scuola di Dottorato Europea in Filologia Romanza. Recuperado de http://www3.unisi.it/ricerca/dottorationweb/filologia

Gutiérrez Nájera, M. (1897). Poesías, ts. II, México: Librería de la viuda de CH. Bouret.

Gutiérrez Viñuales, R. (2003). Roberto Montenegro y los artistas americanos en Mallorca (1914-1919). Anales del Instituto de Investigaciones Estéticas. 25 (82), 93-121.

Hernández, L. R. (2005). Martí y la vigencia de su proyecto modernista. Hipertexto. (1), 20-26.

Herrera y Reissig, J. (1978). Poseía completa y prosa selecta. Caracas: Ayacucho.

Herrera y Reissig, J. (1998). Poseía completa y prosas. México: Fondo de Cultura Económica.

Herrero Gil, M. (2009). Las drogas en el imaginario de Julián del Casal. Anales de Literatura Hispanoamericana. 38, 183-192.

Hobsbawm, E. (2009). La era del Imperio: 1875-1914. Buenos Aires: Planeta-Crítica.

Kwiatkowska-Szatzschneider, T. (1993). La rebeldía romántica: naturaleza y cultura en la prosa de F. Schiller. Iztapalapa. Humanismo y naturaleza. 31, 103-116.

Litvak, L. (1990). España 1900: Modernismo, anarquismo y fin de siglo. Barcelona: Anthropos.

Litvak, L. (2013). Las flores en el modernismo hispanoamericano. Creneida. 1, 134-159.

Leocata, F. (2003). Persona, lenguaje, realidad. Buenos Aires: Universidad Católica Argentina.

López Domínguez, V. (1996). Del yo a la naturaleza por el camino del arte. En O. Market y J. Rivera Rosales (Coords.). El inicio del idealismo alemán. (pp. 281-291). Madrid. Universidad Nacional de Educación a Distancia-Editorial Complutense. 
Luna Sellés, C. (2002). La exploración de lo irracional en los escritores modernistas hispanoamericanos: literatura onírica y poetización de la realidad. Santiago de Compostela: Universidad de Santiago de Compostela.

Marini Palmieri, E. (1998). Julio Herrera y Reissig: la encarnación de la palabra. Caracteres esotéricos del modernismo hispanoamericano. Julio Herrera y Reissig. San José: Universidad de Costa Rica. Recuperado de http://www.biblioteca.org.ar/libros/155031.pdf

Morales, C. J. (1992). Ética y Estética en El reino interior de Rubén Darío. Anales de Literatura Hispanoamericana. 21, 495-505.

Morales Muñiz, M. D. (1996). El simbolismo animal en la cultura medieval. Espacio, Tiempo y Forma. 9 (3), 229-256.

Oviedo, J. M. (1997). Historia de la literatura hispanoamericana 2: Del romanticismo al modernismo. Madrid: Alianza Editorial.

Oviedo, J. M. (2001). Historia de la literatura hispanoamericana 4: De Borges al presente. Madrid: Alianza Editorial.

Perera, N. (1990). La voz y los cánones de Julio Herrera y Reissig. Nova Renascença. IX (3538), 419-432.

Pérez Quintana, A. (2003). Filosofía de la naturaleza y ciencia: Schelling. En J. Montesinos, S. Toledo y J. Ordoñez (Eds.). Ciencia y Romanticismo 2002: Symposium Internacional. (pp. 43-70). Maspalomas: Fundación Canaria Orotava de Historia de la Ciencia. Recuperado de http://es.scribd.com/doc/81656995/Ciencia-y-Romanticismo\#scribd

Phillips, A. W. (1950). La metáfora en la obra de Julio Herrera y Reissig. Revista Iberoamericana. 16 (31), 31-48.

Phillips, A. W. (1974). Temas del modernismo hispánicos y otros estudios. Madrid: Gredos.

Prandi, M. (1995). Gramática filosófica de los tropos. Madrid: Visor.

Programa de Naciones Unidas para el Desarrollo. (2006). Fin de la crisis de agua y saneamiento. Nueva York-Madrid-Barcelona-México: Grupo Mundi-Prensa.

Rodríguez Monegal, E. (1980). El caso Herrera y Reissig: reflexiones sobre la poesía modernista y la crítica. Eco. 37 (224-226), 199-216.

Rodríguez Ocaña, E. (1994). La salud pública en España en el contexto europeo, 1890-1925. Revista de Sanidad e Higiene Pública. 68, 11-27.

Sánchez Calvo, A. (1989). La naturaleza en Alastor, Childe Harold y Endymion. Revista Alicantina de Estudios Ingleses. 2, 143-155.

Sefamí, J. (2000). Neobarrocos y neomodernistas en la poesía latinoamericana. En F. Sevilla y C. Alvar (Coords.). Actas del XIII Congreso de la Asociación Internacional de Hispanistas. Vol. 3. (pp. 420-427). Madrid: Castalia.

Serrano Begega, C. (2012). La obra poética de Federico García Lorca. Salamanca: Universidad Pontificia de Salamanca y Fundación Fidescu. Recuperado de http://www.fidescu.org/ attachments/article/73/Carmen_Serrano.pdf

Tollinchi, E. (2004). Los trabajos de la belleza modernista 1848-1945... San Juan: Universidad de Puerto Rico. 
Todorov, T. (1991). Nosotros y los otros. México: Siglo XXI Editores.

Urdapilleta Muñoz, M. (2014). El bestiario medieval en las crónicas de Indias (siglos XV y XVI). Latinoamérica. 58, 237-270.

Valentini, C. y Ristorto, M. (2015). Bestiarios medievales e imaginario social. Scripta Mediaevalia. 8 (1), 13-24.

Valdeón Baruque, J. (2003). La valoración histórica de la Edad Media: entre el mito y la realidad. Memoria, mito y realidad en la historia medieval. XIII Semana de Estudios Medievales. (pp. 311-329). Nájera: Instituto de Estudios Riojanos.

Voloshinov, V. N. (1976). El signo ideológico y la filosofía del lenguaje. Buenos Aires: Ediciones Nueva Visión.

Yurkievich, S. (1976). Celebración del Modernismo. Barcelona: Tusquets. 
